\title{
Pesquisa de Fatores de Virulência e Classificação Filogenética em Amostras de Escherichia Coli Isoladas de Carcaças de Frango de Granja e "Caipira"
}

\author{
Vanessa Lumi Koga (I), Gabriela Regina Rodrigues (I), Paula \\ Signolfi Cyoia (I), Gerson Nakazato (I), Eliana Carolina Vespero (I), \\ Benito Guimarães de Brito (II), Kelly Cristina Tagliari de Brito (II), \\ Renata Katsuko Takayama Kobayashi (I) \\ (I) UEL - Universidade Estadual de Londrina (Rodovia Celso Garcia Cid Pr $445 \mathrm{Km} 380$ /Cx. \\ Postal 10.011 CEP 86.057-970 ), (II) IPVDF - Instituto de Pesquisas Veterinárias Desidério \\ Finamor (Estrada Municipal do Conde, 6000. Eldorado do Sul / RS)
}

\section{Resumo}

Os produtos de origem animal, principalmente as carnes, são importantes fontes de bactérias responsáveis por enfermidades transmitidas por alimentos. A intensificação da produção tem levado a disseminação de doenças bacterianas como as causadas por Escherichia coli patogênica extra-intestinal (ExPEC). Apesar de E. coli fazer parte da microbiota normal de aves, podem ser patogênicas para os humanos, podendo a carne de frango e seus derivados serem veículos de transmissão dos mesmos. Entre as E. coli causadoras de doenças extra-intestinais, há a E. coli patogênica para aves (APEC), normalmente pertencentes aos grupos filogenéticos A, B1 ou D, e pode apresentar inúmeros fatores de virulência que conferem a ela a capacidade de causar diversas doenças em humanos, como infecções do trato urinário, meningites e septicemias. Neste trabalho, 121 amostras de E. coli foram isoladas de um total de 35 carcaças de frango, comercializadas em supermercados (frangos de granja), e 35 amostras de E. coli de um total de 15 carcaças de frango, originadas da agricultura familiar (frangos caipira), para a pesquisa de fatores de virulência e classificação filogenética. Para a pesquisa dos genes codificadores de fatores de virulência foram pesquisados os genes hlyF

\footnotetext{
Referência:

Vanessa Lumi Koga, Gabriela Regina Rodrigues, Paula Signolfi Cyoia, Gerson Nakazato, Eliana Carolina Vespero, Benito Guimarães de Brito, Kelly Cristina Tagliari de Brito, Renata Katsuko Takayama Kobayashi.Pesquisa de Fatores de Virulência e Classificação Filogenética em Amostras de Escherichia Coli Isoladas de Carcaças de Frango de Granja e "Caipira". In: Anais do 12 Congresso Latinoamericano de Microbiologia e Higiene de Alimentos - MICROAL 2014 [= Blucher Food Science Proceedings, num.1, vol.1]. São Paulo: Editora Blucher, 2014. 
(hemolisina F), ompT (protease de membrana externa), iss (resistência sérica), iutA e iroN (sistemas de captação de ferro), comumente encontrados em plasmídios presentes em APEC, por meio da reação em cadeia da polimerase (PCR). A classificação filogenética, por meio do PCR, baseou-se na análise da presença dos genes chuA e yjaA e um fragmento de DNA (TSPE4.C2). Nossos resultados mostraram que as amostras isoladas de frango de granja apresentaram uma maior quantidade dos fatores de virulência pesquisados, sendo que $74,4 \%$ das amostras apresentaram ao menos um desses fatores, enquanto nas amostras isoladas de frango caipira apenas $25,7 \%$ apresentaram ao menos um desses fatores. Em relação a classificação filogenética, o grupo mais prevalente nas amostras isoladas do frango de granja foi o B1. Já entre as amostras isoladas do frango caipira, o grupo prevalente foi o A. Concluímos que E. coli isoladas de carcaças de frango podem ser reservatórios de fatores de virulência, sendo os isolados de frangos de granja os que mais apresentam esses fatores.

Palavras-Chave: Escherichia coli, fatores de virulência, classificação filogenética

Agência de Fomento: CNPq - ANVISA 